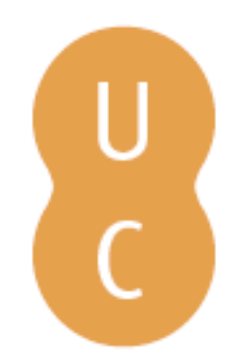

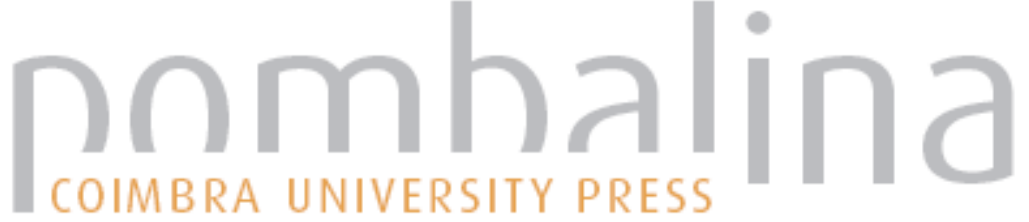

\section{Heteropaternal twins investigation with missing alleged father}

\author{
Autor(es): \\ Ribeiro, T.; Vieira-Silva, C.; Dario, P.; Lucas, I.; Geada, H.; Espinheira, \\ R. \\ Publicado por: Imprensa da Universidade de Coimbra; International Academy of Legal \\ Medicine \\ URL \\ persistente: \\ URI:http://hdl.handle.net/10316.2/31772 \\ DOI: \\ DOI:http://dx.doi.org/10.14195/978-989-26-0173-1_24 \\ Accessed : $\quad$ 26-Apr-2023 13:14:12
}

A navegação consulta e descarregamento dos títulos inseridos nas Bibliotecas Digitais UC Digitalis, UC Pombalina e UC Impactum, pressupõem a aceitação plena e sem reservas dos Termos e Condições de Uso destas Bibliotecas Digitais, disponíveis em https://digitalis.uc.pt/pt-pt/termos.

Conforme exposto nos referidos Termos e Condições de Uso, o descarregamento de títulos de acesso restrito requer uma licença válida de autorização devendo o utilizador aceder ao(s) documento(s) a partir de um endereço de IP da instituição detentora da supramencionada licença.

Ao utilizador é apenas permitido o descarregamento para uso pessoal, pelo que o emprego do(s) título(s) descarregado(s) para outro fim, designadamente comercial, carece de autorização do respetivo autor ou editor da obra.

Na medida em que todas as obras da UC Digitalis se encontram protegidas pelo Código do Direito de Autor e Direitos Conexos e demais legislação aplicável, toda a cópia, parcial ou total, deste documento, nos casos em que é legalmente admitida, deverá conter ou fazer-se acompanhar por este aviso.

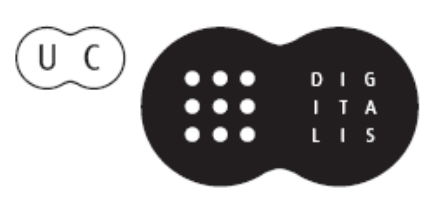




\section{Duarte Nuno Vieira Anthony Busuttil \\ Denis Cusack • Philip Beth}
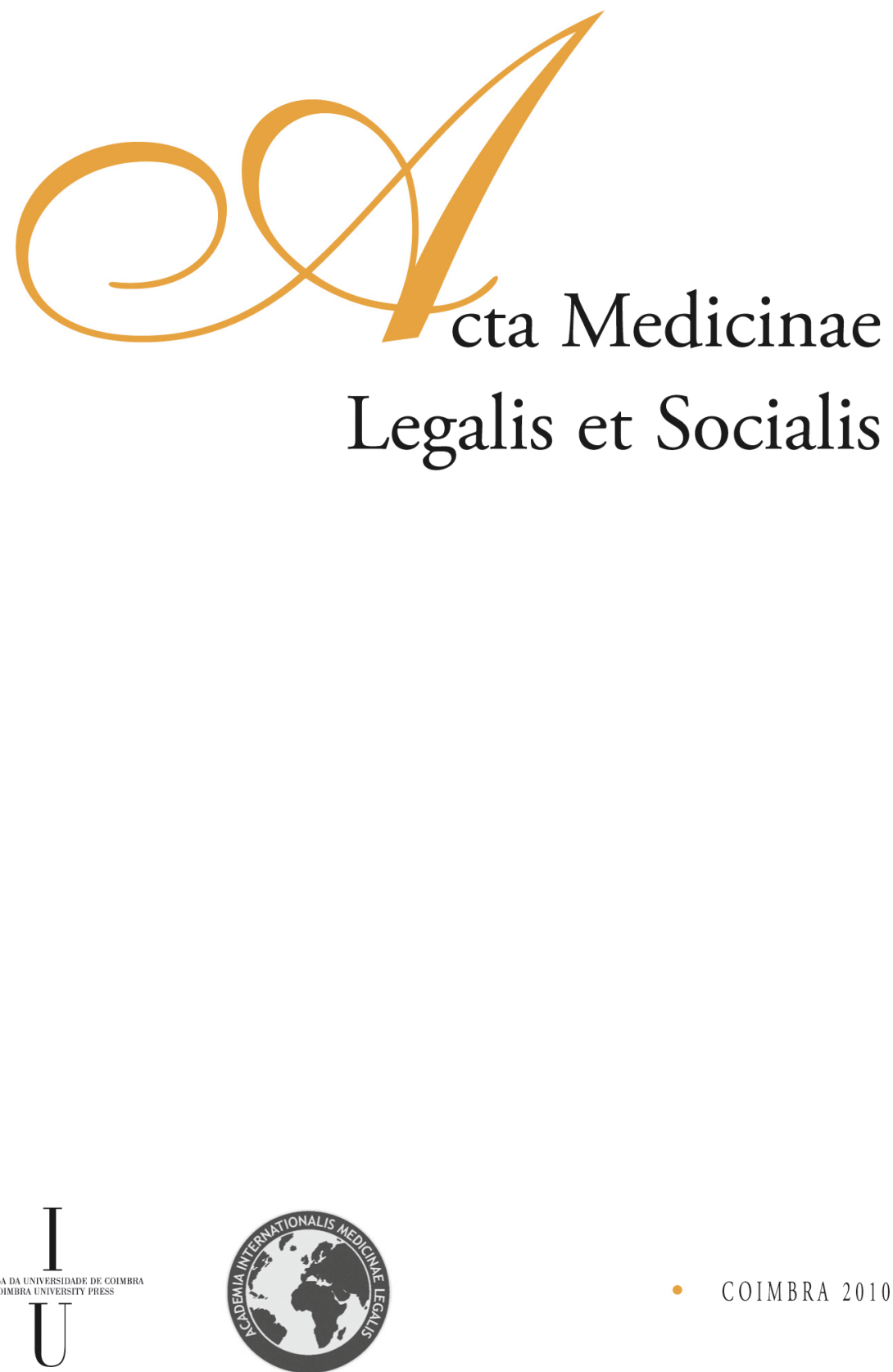
T. Ribeiro' ${ }^{1}$, C. Vieira-Silva ${ }^{1}$, P. Dario ${ }^{1}$, I. Lucas ${ }^{1}$, H. Geada ${ }^{2}$, R. Espinheira ${ }^{1}$

${ }^{1}$ Forensic Genetics and Biology Department, South Branch of the National Institute of Legal Medicine, Lisbon, Portugal

${ }^{2}$ Faculty of Medicine, University of Lisbon, Portugal

\title{
HETEROPATERNAL TWINS INVESTIGATION WITH MISSING ALLEGED FATHER
}

\begin{abstract}
Twins paternity investigation (male and female) was performed as requested by the Court of Justice. As the alleged father was missing, the Court asked for DNA analysis comparison with a biological son of the missing man and their mother. Seventeen autosomal STRs and eleven Y-STR loci were analysed. The results showed that twins had different biological fathers.
\end{abstract}

\section{Introduction}

Superfecundation describes a situation where two ova can be fertilized giving rise to dizygotic twins. Sexual intercourse of a woman during the same polyovulatory period with two different partners may lead to superfecundation with the resulting twins having two different fathers, a phenomenon known as heteropaternal superfecundation. Although rarely among humans, this phenomenon has been described by other authors, particularly involving genetic disease studies and disputed paternities $(1-4)$. In this study we describe a heteropaternal twin investigation in a case of missing alleged father.

\section{Materials and Methods}

DNA was extracted by Chelex method from individual buccal swabs from the twins, the biological son of the missing alleged father and their mother. DNA analysis was performed using AmpF1STR® Identifiler (Applied Biosystem) and PowerPlex ${ }^{\circledR} 16$ System(Promega) to study a total of 17 autosomal STR loci. Additionally, 11 Y-STRs contained in the PowerPlex ${ }^{\circledR} Y$ System (Promega) were investigated. Samples were analyzed in a 3130xl Genetic Analyser (Applied Biosystem) with Genemapper ${ }^{\circledR}$ ID v3.2. Statistical analysis was performed with "Familias" program (version 1.5). 


\section{Results}

After studying 17 autossomic STR loci (Table1), "Familias" program was performed for statistical brotherhood analysis. A twin sisterhood probability of $99,99942 \%$ to the alleged brother and a twin brotherhood probability of $0,00841 \%$ was found. These results were confirmed by Y-STR analysis - six genetic inconsistencies between the male twins and the alleged brother were detected (Fig. 1). These results showed that twins had different fathers.

\section{Discussion and Conclusions}

Performing paternity testing investigations, we have detected several twin heteropaternal cases. The first report on a STR mutation in a double paternity case where both biological fathers were indisputable identified was performed in our laboratory (5). The frequency of twin cases with different biological fathers is probably underestimated, because this phenomenon is mainly detected when paternity investigation is performed. This situation depends not only on whether tests are done, but also on social behaviour (3). Thus, special attention should be taken in similar situations when twins' paternity is being investigated.

\section{References}

1. JAMESWH. Incidence of superfecundation and of double paternity in the general population. Acta Genet Med Gemellol. 42:257-262, 1993.

2. HANSEN, H, SIMONSEN,B. A case of heteropaternal superfecundation in a pair of Danish twin. For Sc. Int. Genetics supplement Series 1514-515, 2008.

3. GIRELA, E. et al. Indubitable double paternity in dizigous twins. Fertil. Steril. 67:115961, 1997.

4. GUINER, S. et al. Two fathers for twin sisters. Int.Cong Series 1239 933-937, 2003.

5. GEADA, H et al, A STR mutation in a heteropaternal twin case. For Sc. Int. 123:239-242, 2001. 
Table1 - Results of the 17 STR loci from twins, their alleged brother and their mother.

\begin{tabular}{|c|c|c|c|c|}
\hline Locus & Mother & Female Twin & Male Twin & Alleged brother \\
\hline D3S1358 & $16-17$ & $15-17$ & $15-17$ & 17 \\
\hline TH01 & $6-8$ & $6-8$ & $6-7$ & $8-9$ \\
\hline D21S11 & $28-29$ & $28-29$ & $28-29$ & $28-31$ \\
\hline D18S51 & $15-17$ & $13-15$ & $13-17$ & 17 \\
\hline PENTA E & $8-12$ & $7-8$ & $7-12$ & $8-12$ \\
\hline D5S818 & $11-12$ & 11 & $11-12$ & $11-12$ \\
\hline D13S317 & 12 & 12 & $11-12$ & $12-13$ \\
\hline D7S820 & 10 & $8-10$ & $8-10$ & $10-11$ \\
\hline D16S539 & 11 & 11 & 11 & $9-11$ \\
\hline CSF1PO & 7 & $7-12$ & $7-12$ & $7-12$ \\
\hline PENTA D & $12-14$ & $5-12$ & $5-12$ & $12-14$ \\
\hline vWA & $15-19$ & $17-19$ & 14-19 & $15-20$ \\
\hline D8S1179 & $12-14$ & $13-14$ & $12-14$ & $12-14$ \\
\hline TPOX & $9-11$ & $8-11$ & $8-11$ & $8-11$ \\
\hline FIBRA & 23 & $23-24$ & 23 & $23-24$ \\
\hline D2S1338 & $16-23$ & $16-25$ & $16-25$ & $16-22$ \\
\hline D19S433 & $13-14.2$ & $13-14$ & $14-14.2$ & $12.2-14.2$ \\
\hline
\end{tabular}




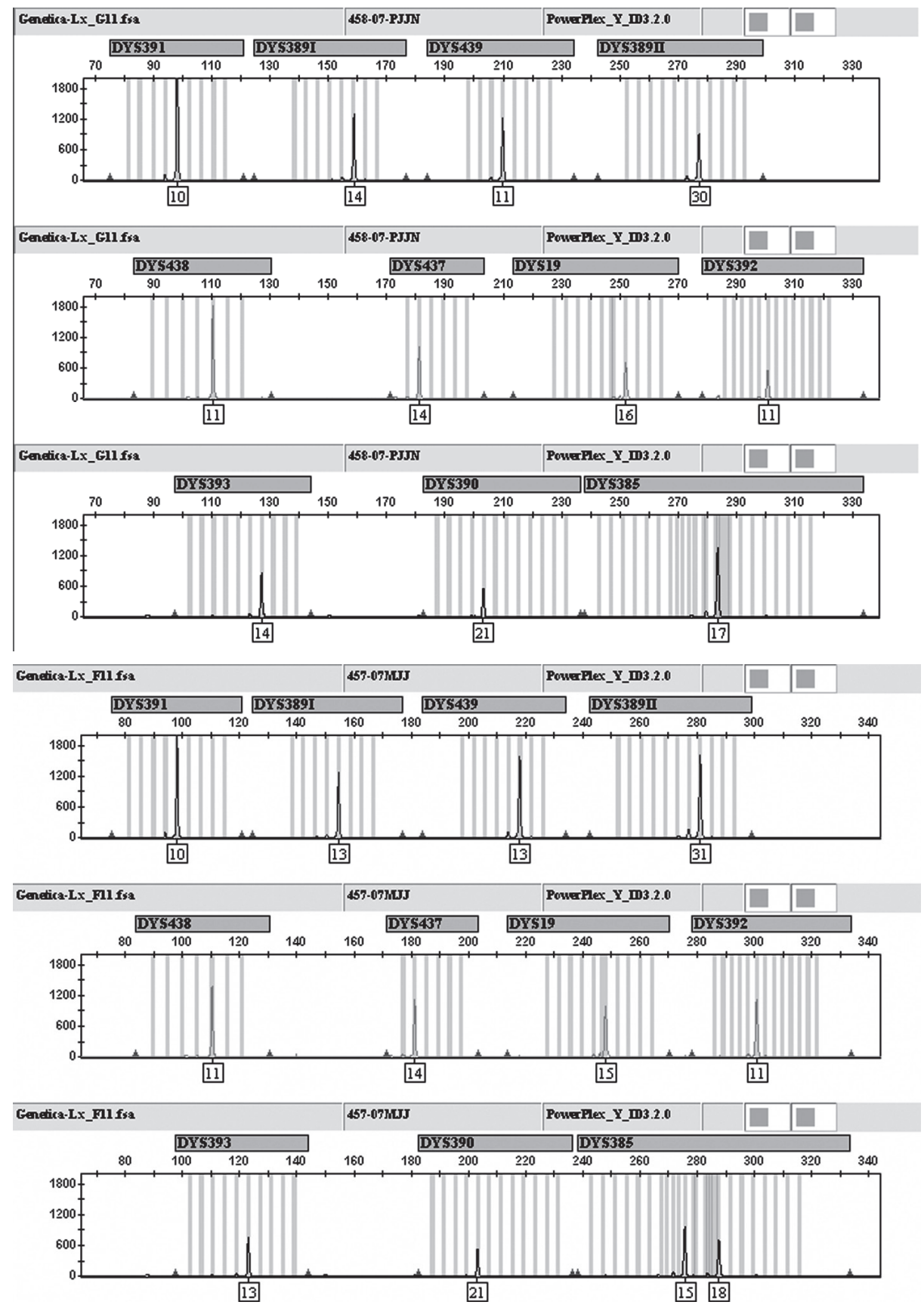

Figure 1 - Y-STR electropherograms of the alleged brother (A) and the twin male (B) showing six genetic inconsistencies in DYS391I, DYS439, DYS391II, DYS19, DYS393 and DYS385 loci. 